\title{
The Role of Spiritual and Theological Literature in Tatar Culture of the XVIII and Early XX Centuries
}

\author{
Gabdulzyamil G. Zaynullin ${ }^{1}$ \\ ${ }^{1}$ Kazan (Volga Region) Federal University, Kazan, Russia \\ Correspondence: Gabdulzyamil G. Zaynullin, Kazan (Volga Region) Federal University, 420008, Kazan, \\ Kremlyovskaya Street 18, Russia. E-mail: jam.zayni@kpfu.ru
}

Received: June 15, 2015 Accepted: June 24, 2015 Online Published: June 30, 2015

doi:10.5539/jsd.v8n7p193 URL: http://dx.doi.org/10.5539/jsd.v8n7p193

\begin{abstract}
The urgency of the problem under investigation is caused by the growing interest in the spiritual roots of national cultures, where there is Tatar culture among their number. Religious and theological literature is an essential part of the Tatar national culture and has played an invaluable role in its formation process. The purpose of the article is to identify the most significant works of the Tatar theological and spiritual literature of the period studied, to classify, to establish their basic cultural, historical, linguistic, functional and stylistic features. The leading methods of investigation used were the descriptive-comparative method and structural-linguistic analysis. These methods made it possible to observe the complex process of development of the Tatar religious literature from the XVIII century to the first decades of the XX century and to identify the main features of this process. It was determined that the Tatar theological literature of the XVIII - XIX centuries was enduring the same processes as the literary language of the same period. The most prominent and well-known works of the Tatar theological literature of the time were created by the intellectuals, who were known as the most educated part of the society, encyclopedic scientists fluent in several languages. Materials of the article can be useful to university teachers dealing with the courses on the history of Tatar literature, to oriental literature researchers, students and post-graduate students.
\end{abstract}

Keywords: Tatar theological literature, Tatar spiritual literature, Quranic exegesis, hadith

\section{Introduction}

\subsection{Urgency of the Problem}

In modern multinational and multi-confessional Russia theological experience of different nations and religions living in the country plays a very important role. In Russia, especially in the life of Volga basin Tatars, Islam possesses a rich tradition of religious and reformatory ideas. The history of the Tatar people shows that there was the period of cultural and civilizational revival at the turn of XIX - XX centuries, and it coincided with replacing of the traditional worldview with a new worldview based on a rational rethinking of all aspects of human life, including such a category of consciousness as faith. Tatars' awareness of their faith - Islam - nature paved the way for the harmonious development of the Tatar society, their tolerant coexistence in a multi-confessional country and their dynamic entry into the process of world community globalization.

Spiritual literature or literature with some religious content takes a significant layer of the Tatar culture. It was originated on the bases of translations from the Arabic, Persian and Ottoman-Turkish languages in to Tatar which were creatively processed by Tatar Muslim theologians (Bigiyev, 1905). We can rank among them the comments of the Koran and hadith (legends about the speeches and actions of Muhammad the Prophet, which affect various religious and legal aspects of the Muslim community life (Islam, 1991)), the Koranic and the hadith studies, didactic and other edifying literature.

\subsection{The Need for Historical and Linguistic Research of Tatar Theological Literature}

At the present time, due to the growing interest in the spiritual roots of Russian national cultures, spiritual literature is becoming the object of diverse researches of different types where there are philological, philosophical, historical and many others among them. Therefore there is a need to explore it in a historical and linguistic frame.

The Tatar spiritual literature plays a special role in the history of Russia peoples' literature. The range of issues 
raised in the Tatar theological thought of the XVIII and early XX centuries include both purely dogmatic problems associated with the Islamic faith, with the Islamic law and also the problems of philosophical, historical, social, political, as well as the issues of scientific knowledge methodology. At the same time theoretical and practical study of this vast layer of cultural heritage still leaves much to be desired.

The practical value of this article is determined by the possibilities of using it in high school courses on the history of Tatar literature in particular and Turkish literature in general. It also can be used on the translation practice in the process of describing the common history of Turkish literature, and developing of the problems associated with the theory of literature.

The problem of the Tatar theological literature had been studied by a number of scientists. Among the most famous works of the last two decades there are the «Islam in Tatar social thought in the beginning of the XX century» by R.M. Mukhametshin (Mukhametshin, 2000), «Tatar religious and philosophical thought in the context of a general Muslim religion» by T. Ibrahim, F.M Sultanov and Yuzeev (Ibrahim, Sultanov \& Yuzeev, 2002). Monographic study of Tatar theological literature of the XVIII - XX centuries belongs to the author of this article too (Zaynullin, 1999).

\section{Methodological Framework}

The study had been conducted in the following areas:

- Working in libraries and private archives with the aim of detecting different patterns of Muslim Tatar literature.

- Studying the socio-political, cultural and historical situation in which these written sources appeared.

- Inventorying, general describing, identifying the origins and traditions, as well as the classifying of manuscripts and printed versions of religious and theological literature in the Tatar and other Turkic languages; functional-stylistic and structural-linguistic analysis of Tatar theological literature samples of the XVIII and early XX centuries.

The main objective of the research is identifying the most important features of the Tatar theological literature of the XVIII and early XX centuries and the main stages of its development.

It is generally known that some of the Tatars profess the Orthodox branch of Christianity and have their religious literature, but it should be the object of a separate study.

The work under the study is based on a descriptive and comparative methods, and the method of structural and linguistic analysis.

\section{Results}

\subsection{The Koranic Tafsir Role in the Development of Tatar Theological Literature}

The importance and prevalence majority in Tatar spiritual literature belongs to the comments of the Koran which are known as Tafsir. The same is true for the whole Muslim spiritual literature. They were popular not only among the Muslims of Russian, but also in Turkey, Eastern Turkestan, Japan, Korea, which were the home for the Turkic-speaking diaspora. Undoubtedly, the Koran «had shaped and continues shaping the religious beliefs of Muslims and, indeed, it remains as the central text in the cultures of many Muslim nations» (Wild, 1996). The Canadian scientist Andrew Rippin's thoughts about assessing the value of commentaries on the Koran are very important «Just through the exegetical works we can learn the history of readers' reactions to the Quran and obtain the meaningful approach to the analysis and understanding of the Koran ... We reach the aim which satisfies us intellectually just studying what exactly Koran expresses in the eyes of Muslims» (Rippin, 1998).

It is a common knowledge for the scientific field that one of the earliest Turkic-speaking tafsirs is the tafsir created in the XII-XIII centuries in Central Asia and found in Karshi town on the territory of Uzbekistan (Borovkov, 1963). This Commentary is regarded by the researchers as an important monument of the Turkic literary language of Kara-khanid period (Eckmann, 1976). We can confidently assert that this tafsir had a serious impact on our later studies.

The study of the Koran tafsirs which exist in the Tatar language makes it possible to prove that the commentators were not stuck to a literal translation of the original text. They also referred to historical sources in Arabic, Persian, Ottoman-Turkish, supplementing their works with new information. However, none of these authors recap his colleges' ideas. In each of the books under consideration there is the different style of commenting: «Taskhil al-Bayan» (Imankul 1910 - 1911, Kazan), (1996, Doha), «al-Itkan» (al-Hamidi, 1907-1911, Kazan), (1949 Tokyo), «Tafsir by Nugmani» (Nugmani, 1911) and others.

Generalizing the interpretation of certain verses, retelling of the same meanings and some tautology caused by 
that is a characteristic feature of the Tatar tafsirs: «Perfection and the qualities praised is inherent to Allah alone. In this regard there is no one equal to Him because of His incomparability, so identification of qualities praised and praising is inherent to Allah only, and no one else is able to do that ..» (Nugmanov, 1911).

In the tafsir «al-Itkan ..» we can find a lot of related stories, legends connected with the history of Islam, the names of Allah, the followers of Muhammad the Prophet, with the fact of Islam spreading in the Arabian Peninsula. Also there are numerous explanations for godsend surahs and verses of the Koran: «Allah - He is the embodiment of all the excellent qualities which exist, truly there is no god but Him, and only Allah the Almighty embodies all the finest qualities. Allah is always alive (who is). Prophet the Generous says: The majestic name of Allah the Almighty mentioned in three suras, one of them is the sura «The Cow».

Historical information is mostly found in the tafsir «Taskhil al-Bayan» (Imankulyi, 1996): «The reason for the revelation of eighty verses at the beginning of the surah was the event associated with the delegation of Najran. The delegation of Najran is a group of Christians from Najran land, who arrived to Medina. Their goal was to debate with the messenger sallallaahu 'alaihi wa sallam, Gais (Jesus), let him be welcomed ...»

The new scientific approach to the Koran study was firstly offered among the Turkic Muslims by a prominent Tatar scientist, theologian Rizaeddin Fakhretdinov. His point of view on the problem he outlined in his book «Kuran wa tibaat» (Koran and publishing) (Fakhretdinov, 1900). According to the author, the first printed Koran in Europe was issued in 1649 in Hamburg. However, in the scientific and bibliographic reference of the Koran translation into the languages of the world, published in Istanbul in 1986, there is the information about an earlier date, namely 1543 .

\subsection{Exposition of the Best Known Muslim Stories into the Tatar Language as the Stage of Spiritual Literature Development}

Along with the interpretation of the Koran, translations and commentaries of the hadith there was a need in retelling, exposition into the Tatar language the best known stories of Muslim literature. According to a well-known specialist in Turkic philology L.V. Dmitrieva among the Tatar manuscripts there are often a good deal of abridged translations and expositions of Arabic religious writings with the comments added. Dmitrieva underlines the fact that in the Volga-Urals habitat there dominated the local history (of a semi-legendary character) and the religious educational literature and tutorials on different areas of knowledge of the XIX - XX centuries.

The process of selecting works for translation was not accidental. Great importance was attached to the educational and ethical peculiarities of the works. For example, in the preface to the book «Tarikai Muhammadiya» it is written that: «Among our brothers in faith there are those who cannot always turn the Arabic books to the appropriate advantage. Our goal is to help them, so that's why we translated "Tarikai Muhammadiya" into our native language». In the two books, the important consideration is given to the commentaries of separate verses of the Koran and Hadith.

Thus, there are many varieties of ethical and didactic literature like "Muhtasar al-Kuduri" («A short set of al-Kudur»), "Ayn al-Ilm" («Source of knowledge"), "Muhammadiya" Celebi, which was established basing on the stories of Muhammad the Prophet's companions and first published in Kazan in 1845, edited by an orientalist Mirza Kazembek, "Qissas al-Anbiya" («Stories about the Prophets") and others. Some of these works were republished several times. So, "Muhtasar al-Kuduri" was published 15 times (1880-1916 gg.) and twice a year in some particular cases.

"Alti Barmak" («Six fingers"), which obviously refers to six tarikats in Sufism was very popular among the religious-didactic works of the Volga region.

As the factual material it is appropriate to cite as an example the manuscripts "by an unceremoniously seminarian socialist" (Klyuchevskii, 1990) N.G. Chernyshevsky, which are dedicated to Tatar spiritual literature and which relate to the period of his training in Saratov Orthodox Theological Seminary. The content of these manuscripts had been described in the author's own interpretation (Chernyshevsky, bg).

Among the manuscripts written in Arabic script there are mostly historical legends from the life of Muslim saints, as well as samples of the Tatar theological literature such as Munajat and Bait, spiritual and religious poems dedicated to Gais the Prophet (Jesus) and to his mother Maryam (Mary), to Muhammad the Prophet... and the whole literary work, known in the Tatar literature as "Kyssai Avyk" ("Legend of the gazelle"). The work is written in a beautiful Arabic handwriting which is known as «nash» and begins with the traditional Muslim glorification «With the name of Allah, Most Gracious and Most Merciful».

The language of the poem is full of Arabic, Persian, Ottoman-Turkish vocabulary and abounds with different 
grammatical features, but at the same time all the stylistic originality can be considered as the traditional elements of the old Tatar written language. According to some scholars, some inherent conservatism is typical for theological literature and for cultic language (Avrorin, 1975).

To our point of view, all the samples of Tatar spiritual and religious literature have been selected by the author with a certain intent, which is relevant to some rules of Orthodox theological seminaries of the Russian Empire, the graduates of which had to work as missionaries in those places where the Muslim population was living - in the Volga region, in Siberia, in the Caucasus, in the Crimea, in Central Asia, as well as in Syria, Palestine and other regions.

Poetic legends are represented exclusively with spiritual and religious poetry of a didactic content. There are several fragments taken from the Sufi writings by Tatar authors.

An interesting feature, though borrowed from Arabic literature, is the traditional anticipation of legends (hadith) and stories by the following expressions: "The reason of the revelation of this noble verse is described like ..."

"They say that one day a wicked man swiped Imam Azam by his hand ..."

"Uzeyr, let him be greeting was from the family of Yaakub the prophet..."

As for the Tatar language in all the spiritual literature, undoubtedly, we feel the significant influence of the Central Asian and Ottoman-Turkish languages. As for the artistic wealth of the language in the books we reviewed written by Tatar theologians in the Turkic-Tatar, Arabic languages or in the works translated from Arabic, Persian into their native language. The vast majority of these books are in no way inferior to the same literature, created in the Middle Asia, Turkey and Arabic countries. Proof of this are such works as "Nazurat-al-Hak" (Review of the truth, Marjani), "Al-Irshad lil-Ibad" («Admonitions to the religious»), "Tafsir al-Quran" («Commentary on the Koran") by Kursavi , "Quran wa al-Masahif" («History of the Koran and its scrolls»), "Islahat asaslari" («Fundamentals of reforms»), "Ayam hayat an-Nabi" («Life story of the Prophet") by M. Bigiyev. These and many other literary monuments have not lost their relevance even today.

\section{Discussions}

In some scientific works there are the relevant comments on some sources we have studied. A special place is occupied by the works of such scholars as G. Kursavi (1903), S. Marjani (1870), M. Bigiyev (1907), R. Fakhretdinov (1900), Z. Kamali (1913), Ibrahim A. (1907) Al Hamidi (1907-1911), MS al-Imankul (1910-1911) and others. These scientists were convinced that Islam was not against the achievements of modern science, but, on the contrary, contributes to its development. Their competence in the matter can be judged by their scientific works and practical activities aimed at educating and maintaining the moral and ethical foundations of the people. It is important to note that these authors used dozens or even more sources in the Arabic, Persian, Turkish, and other languages.

In our study, we examined the Tatar theological literature primarily in structural and linguistic aspects.

There were different views about Tatar spiritual literature. Especially, that it is "unlike Chaghatay and Ottoman theological literature turned to be weaker and featureless" (Rahim, 1925). The examples and spiritual monuments of the Tatar literature we considered refute this assertion, showing the richness of the language, developed stylistic system, and respect for the traditions of Islamic literature. High ethical, aesthetic, cultural and historical value of these works makes the researchers, writers and public figures to refer to them again and again. We believe that this important layer of literature is worthy of careful scientific study.

\section{Conclusion}

The study leads to the following conclusions:

1. Theological literature has been an important area of functioning of the Tatar-written literary language for centuries. The same processes were happening in it as in the literary language of the period. It was caused by the literary influence of other languages, traditions, by the general focus on the people's spoken language and other factors.

2. Tatar theological literature had been created by the members of the most educated part of the society, who were fluent in several languages in Arabic, Persian, Ottoman-Turkish, as well as perfectly mastered writing and the literary language of their era.

3. The revival of spiritual culture and aspirations of the people to return to their roots lead to a need of versatile and deep study of manuscript versions of written monuments of earlier centuries and to the process of returning the heritage to the general reader. This causes a new problem of creating bilingual dictionaries, including the 
Arab-Persian dictionary of phraseology in the Tatar language, as well as other thematic directories.

\section{Recommendations}

Materials of this article are valuable to the researchers of Tatar literature, students of religion and all people interested in the Tatar culture of the XVIII - XX centuries or Islamic Studies. The article can also be useful to students and graduates of Oriental, philological, historical and specialties, to teachers, literature and public figures. We hope that the results and conclusions presented will serve as a basis for further scientific work in this area.

\section{Acknowledgments}

The work is performed according to the Russian Government Program of Competitive Growth of Kazan Federal University.

\section{References}

Al-Khamidi. (1907-1911). Al-Itkan fi tardzhimati-l-Kuran. Kazan.

Approaches to the History of the Interpretation of the Quran. (1988). Oxford: Clarendon Press, 1-4.

Avrorin, V. A. (1975). Problemy izucheniya funktsional'noi storony yazyka: (k voprosu o predmete sotsiolingvistiki). Moscow: Nauka.

Bigiev, M. (1907). Al-Luzumiiat. Kazan', 27.

Bigiev, M. (1909). Al- Muafakat. Kazan'.

Bigiev, M. (1910). Kavaidu fikkhiia. Kazan'.

Borovkov, A. K. (1963). Leksika sredneaziatskogo tafsira XII - KhIII vv. Moscow, 13-14.

Chernyshevskii N.G. V rukopisi, fond 1, opis' 1, edinitsa khraneniya 298. Moscow, Tsentral'nyi Gosudarstvennyi arkhiv literatury i iskusstva.

Dmitrieva L. V. (1987). Tyurkoyazychnaya arabopis'mennaya rukopisnaya kniga po ee arealam. V kn. Rukopisnaya kniga v kul'ture narodov vostoka. Moscow, 407.

Eckmann, J. (1976). Middle Turkic Glosses of the Rylands Interlinear Koran Translation. Budapest, 3.

Fakhretdinov, R. (1900). Koran wa tibaat (Koran i knigopechatanie). Kazan'.

Fakhretdinov, R. (1900-1904). Asar v 4 chastyakh. Kazan'.

Ibragim, A. (1907). 1001 khadis. St. Petersburg.

Ibrakhim, T., Sultanov, F. M., \& Yuzeev, A. (2002). Tatarskaya religiozno-filosofskaya mysl' $v$ obshchemusul'manskom kontekste. Tatarskoe knizhnoe izdatel'stvo.

Imankulyi, M.-S. (1910-1911). Taskhil al-baian fi-t-tafsir al-Kuran. Kazan'.

Imankulyi, M.-S. (1996). Taskhil al-baian fi-t-tafsir al-Kur'an. Dokha

Islam: Entsiklopedicheskii slovar'. (1991). Moscow: Nauka.

Kamali, Z. (1913). Dini thdbirlђr. (Dini tedbirler)

Khalidov A. B. v kn. Ocherki istorii arabskoi kul'tury V-KhII vv. (1982). Moskva, 234.

Klyuchevskii, V. O. (1990). Etnograficheskie sledstviya russkoi kolonizatsii Verkhnego Povolzh'ya. Istoricheskie portrety.

Kursavi, G. (1903). Al-irshadu lil-ibad. Kazan'.

Kursavi, G. Tafsire khaftiyak. (V rukopisi) Otdel redkikh knig KFU. 2181, 2185, 2189.

Mardzhani, Sh. (1870). Nazurat al'-khakk fi fardyiat al'-isha va in lyam iagyb ash-shafak. Kazan'.

Mukhametshin, R. M. (2000). Islam v tatarskoi obshchestvennoi mysli nachala XX veka. Izd-vo" Iman".

Nugman. (1914). Kor"en tafsire. Kazan'.

Porokhova, V. (1996). Koran. Perevod smyslov i kommentariev. Damask-Moskva.

Rakhim, G. (1925). Istoriya tatarskoi literatury. Kazan', 149.

Rippin, A. (1998). Literary Analysis of Koran, Tafsir, and Sira: The Methodologies of John Wansbrough. The Origins of the Koran: Classic Essays on Islam's Holy Book. Prometheus Books. 
Validov, Dzh. (1923) Ocherk obrazovannosti i literatury volzhskikh tatar. Vyp.1. Moscow-Leningrad, 66.

Wild, E.S. (1996). The Quran as Text. Leiden: Brill, XIII.

Zainullin, G. G. (1999). Tatarskaya bogoslovskaya literatura 18-n. 20 vv. i ee stile-yazykovye osobennosti.

\section{Copyrights}

Copyright for this article is retained by the author(s), with first publication rights granted to the journal.

This is an open-access article distributed under the terms and conditions of the Creative Commons Attribution license (http://creativecommons.org/licenses/by/3.0/). 